\title{
Profile of the Sri Lankan Electrical Engineering Industry
}

\section{Buddhika Jayasekara, Rohan Lucas, Satish Namasivayam and Lanka Udawatta}

\begin{abstract}
The electrical and electronic industry in Sri Lanka, although relatively small in itself, is a key service industry to other industrial sectors as well. In the study presented, a sample of around 300 companies/industries has been the surveyed from around 500 identified companies to obtain the profile of the electrical engineering industry. From the surveyed companies, more than $76.8 \%$ are in the electrical industry and these companies account for over $81.1 \%$ of the total employment provided. The energy supply sub sector provided $36.7 \%$ of the total employment, and is influenced heavily by the large workforce of the CEB. The electrical services industry, which is mostly dominated by the small enterprises, contributes to $20.9 \%$, while electrical products sector accounts for $23.5 \%$ of the employment.
\end{abstract}

The majority of the industry's employment is concentrated in the operational grades $(75.8 \%)$ where the technical skills requirements are quite specific for a particular role and quite diverse for different roles. The skills requirement becomes more generalized, with more emphasis for managerial qualifications, as one goes higher up in the occupational structure.

At the operational levels, the vast majority of the workers are with either GCE O/L or A/L qualifications (65.2\%). On the other hand, higher education qualifications are much more sought after at the managerial level and decision making level with $72.2 \%$ of the managers and $88.8 \%$ of the decision makers possessing a degree or above qualifications.

The growth potential of the electrical and electronic industry has been estimated, based on census and statistics of GDP growth rates of similar industries, by categorising the industry into five sub-sectors, namely energy supply, electrical products, electrical services, export oriented electronics, and local consumer electronics and services. The forecasted annual growth of employment for the industry is $14.4 \%$ (Electrical industry $13.7 \%$ and electronics industry $16.8 \%$ ).

Keywords: $\quad$ Profile, Electrical, Electronic, Engineering, Industry, Survey

\section{Introduction}

The electrical and electronic industry plays an important part in the global industrial landscape as a key service industry to other industrial sectors as well by creating large quantities of employment opportunities.

The paper is based mainly on a study that the authors, together with some of their colleagues, have undertaken for the Tertiary and Vocational Education Commission of Sri Lanka. The paper analyses the profile of the electrical and electronic engineering industry and tries to match the training with that required by industry. The electrical and electronics industry in Sri Lanka, is centred in the Western Province (Figure 1.1), and that too mainly around Colombo.

Presently only the Universities, both local and foreign-affiliated, offer Electrical and Electronics Engineering Degrees. In addition, there are number of other institutions that offer Certificate and Diploma courses.

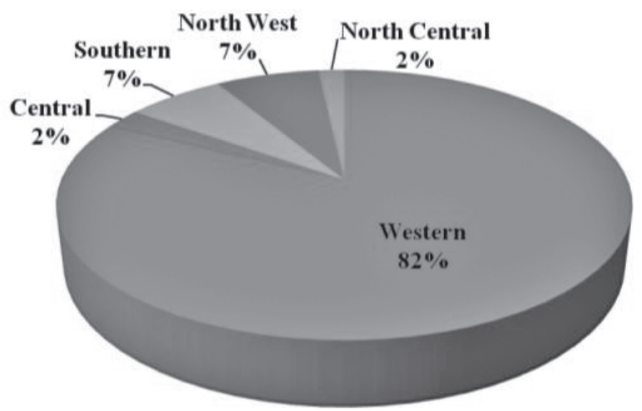

Figure 1.1- Geographical distribution of establishments

Eng. (Dr.) Buddika Jayasekera, B.Sc. Eng. (Moratuwa), PhD. (Saga), Senior Lecturer, Grade II, Department of Electrical Engineering, University of Moratuwa.

Eng. (Prof.) Rohan Lucas, Int. PEng.(SL), C. Eng., FIE(Sri Lanka), FIEE, B.Sc. Eng. (Ceylon), M.Sc. (Manchester), PhD. (Manchester), Professor of Electrical Engineering, University of Moratuwa.

Dr. Satish Namasivayam, B.Sc (Hons), M.Phil(Colombo), MBA(Colombo), Ph.D(Sweden),Senior Lecturer, Grade I, Department of Electrical Engineering, University of Moratuwa

Eng. (Dr.) Lanka Udawatta, BSc Eng(Moratuwa), MEng(Saga), PhD(Saga), Professor of Electrical Engineering, University of Moratuwa.) 


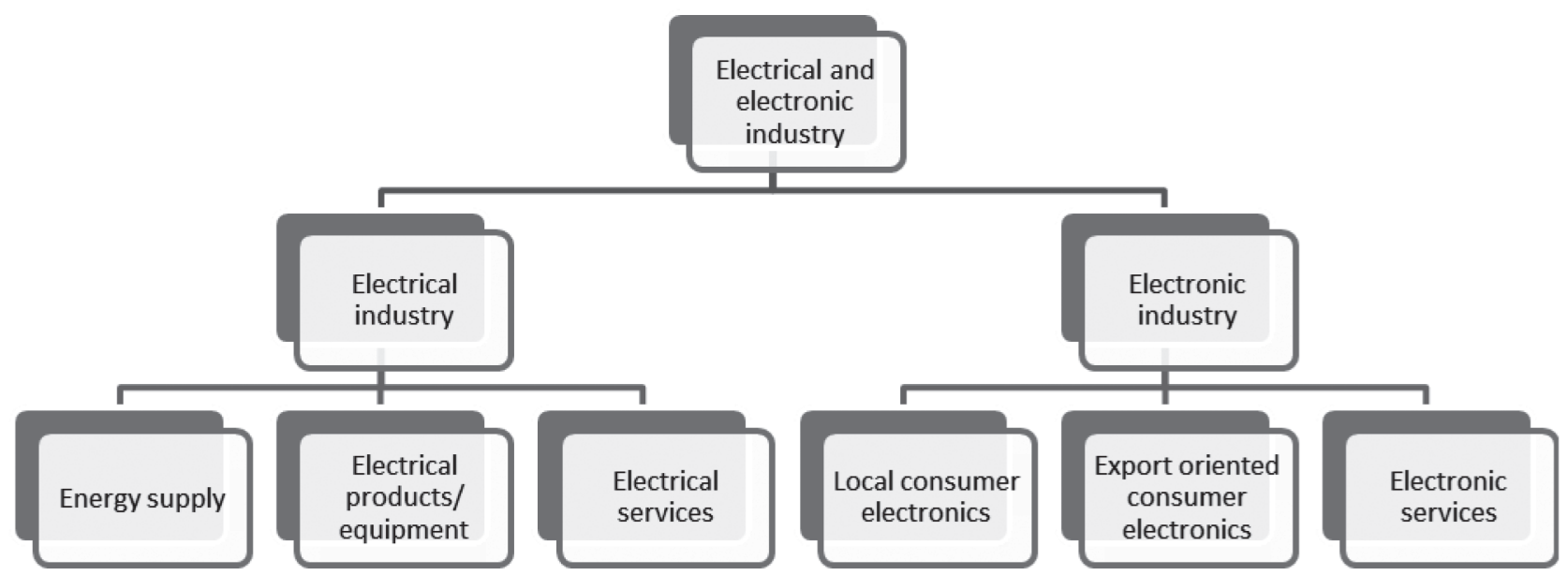

Figure 2.1- Categorisation of Electrical and Electronic industry

There are also government institutions that offer vocational and short duration courses.

\section{Methodology}

\subsection{Data Collection}

Data collection was mainly through two survey questionnaires developed to achieve the objectives. Relevant industries were surveyed mainly to capture the industry profile and the human resource profile while the training institutions were surveyed to explore the available training capacity.

Face-to-face interviews, and e-mail based information enhanced the data collection. Clarifications on the answers provided were taken over the phone whenever required.

\subsection{Determination of Industry Profile}

In the determination of the Electrical and Electronic Engineering Industry Profile, the economic environment of the industry sector was targeted through the survey which was designed to capture the following information.

(a) Distribution of the Industry based on the Geographical distribution, and sector-wise distributions based on BOI and Non-BOI.

(b) Nature of the Industry based on products and services output and their composition in export market and local market.

(c) Technological level based on the main areas of operations in electrical and electronics industry (Figure 2.1).

\subsection{Determination of Human Resource Profile}

In the determination of the Human Resource Profile, the following was performed through the survey: (a) An occupational mapping exercise to map the available occupations and the occupational categories.

(b) Distribution of the currently employed population by occupation, sex, district, age group, and educational level.

(c) Estimated manpower requirement in different categories of employment of the sector for next five years.

\subsection{Determination of Training Profile}

In order to capture the details regarding the existing training positions, the following information was captured from the survey:

(a) Currently available training positions by sector, district and mode of training.

(b) Deficits and excesses in the training provisions; calculated in comparison with the manpower requirement of the industry.

\subsection{Extrapolations from the Survey}

In the survey, in a given sub-categorisation, exact numbers of employees could be obtained only for the CEB. Thus the total employment obtained from the survey has to be adjusted to correspond to the fact that not all employees in the electrical and electronic sector are being sampled. From available information [3] the non-CEB employees in the sector, extrapolated for 2011 is 37,734 . The corresponding number caught by the survey is 18,548 . This gives a multiplying factor of 2.03 for correcting the data from the survey. Thus a factor of 2 was used in the analysis to correct all other sectors other than the CEB employees to obtain the total workforce.

The total workforce of the country is distributed among the main economic sectors: agriculture $(32.5 \%)$, industry $(24.6 \%)$ and 
services $(42.9 \%)$. The informal sector of the economy also plays a major role in the employment opportunities and income generation in the country.

The overall contribution of the informal sector employment is $62.6 \%$, and $37.4 \%$ is from the formal sector [4]. The informal employment opportunities in the electrical and electronics industry sector are concentrated in areas such as self-employed personnel in electrical and electronics services sector, small scale home businesses and small scale industries. The majority of the trained personnel in operational grades find employment in informal industry sector and is assumed to correspond to the value of $62.6 \%$. The current training capacity, for the formal sector, is thus calculated by assuming that the only $37.4 \%$ of the trained personnel remain.

Growth rates of the "energy supply" and "electrical services" subsectors are estimated based on the GDP growth rate of "electricity" category (around 10\%), while the growth rates of other sub sectors are estimated based on the GDP growth rate of the "factory industry" category (around 15\%) [5].

\section{The determined Profiles}

\subsection{Industry Profile}

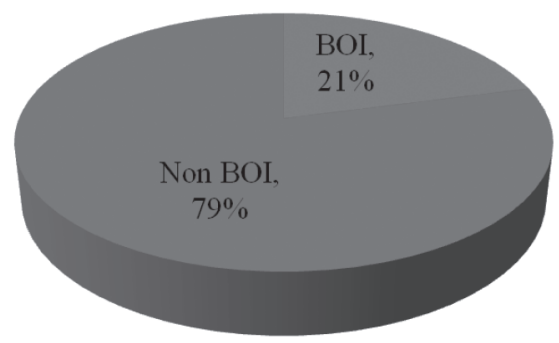

Figure 3.1- BOI and Non - BOI distribution

The survey shows that around $21 \%$ of the establishments surveyed are BOI companies (Figure 3.1).

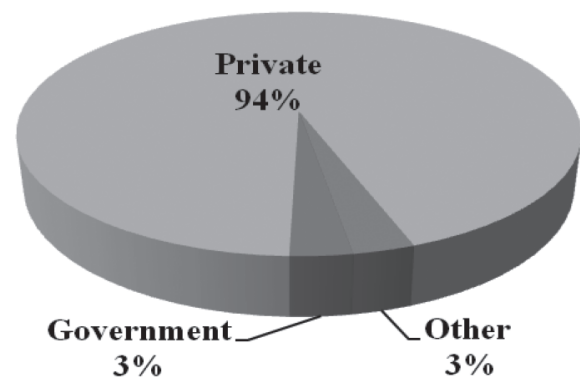

Figure 3.2- Distribution by ownership

It also shows that the majority of the companies engaged in the electrical and electronic industry is in the private sector (Figure 3.2).
The study has also shown that the manufacturing industry is primarily assisted by the foreign investments. The key products manufactured are transformers, switches, plugs, holders, electric panel boards and electrical cables.

Electronics manufacturing industry is focused on production of a range of electronic components such as magnetic heads, ferrite cores, fiber optic related products, printed circuit boards, compact fluorescents, memory modules, toroidal coils, thermal outfits, bio medical engineering products, household appliances and energy saving lamps.

The Electrical and Electronic export market is mainly driven by the foreign investments. To achieve quality of products, these require skilled labour and qualified middle managers.

Table 3.1- Employment by area of operation

\begin{tabular}{|c|c|c|c|c|c|}
\hline Field & Sub Category & $\begin{array}{c}\text { No. of } \\
\text { Companies }\end{array}$ & $\%$ & $\begin{array}{l}\text { Total no. of } \\
\text { Employees }\end{array}$ & $\%$ \\
\hline \multirow{3}{*}{ 䒿 } & Energy supply & 17 & 8.2 & 10,103 & 36.7 \\
\hline & $\begin{array}{l}\text { Electrical products } \\
\text { / equipment }\end{array}$ & 51 & 24.6 & 6,480 & 23.5 \\
\hline & Electrical services & 91 & 44.0 & 5,760 & 20.9 \\
\hline \multirow{2}{*}{ 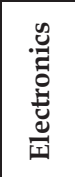 } & $\begin{array}{l}\text { Export oriented } \\
\text { electronics }\end{array}$ & 6 & 2.9 & 4,093 & 14.9 \\
\hline & $\begin{array}{l}\text { Local consumer } \\
\text { electronics and } \\
\text { electronics services }\end{array}$ & 42 & 20.3 & 1,099 & 4.0 \\
\hline
\end{tabular}

Table 3.1 shows the distribution of the companies and the employment within each sub-category for 207 valid responses from a sample of 300 companies.

\subsection{Human Resource Profile}

The human resource profile is categorized into the following key areas

1. Electrical Industry
a. Energy supply
b. Electrical products/equipment
c. Electrical services

2. Electronic Industry
a. Export oriented electronics
b. Local consumer electronics and electronic services

In each of the above categorizations, the occupational structure is broadly identified at the following level of hierarchy.

- Decision making level

- Managerial level

- Supervisory level

- Experienced skilled or skilled worker level

- Basic or semi-skilled worker level 
The National Vocational Qualification (NVQ) Levels in Sri Lanka identifies seven levels for award of certificates [6]. These levels are equated to the identified hierarchy as given in table 3.2.

Table 3.2- Occupational categories with NVQ levels

\begin{tabular}{|c|c|c|}
\hline \multicolumn{2}{|c|}{ Category } & $\begin{array}{l}\text { NVQ } \\
\text { Level }\end{array}$ \\
\hline \multicolumn{2}{|c|}{ Decision making } & 7 \\
\hline \multicolumn{2}{|c|}{ Managers } & 6 \\
\hline \multicolumn{2}{|l|}{ Supervisors } & 5 \\
\hline \multirow{2}{*}{$\begin{array}{l}\text { Operational } \\
\text { Grades }\end{array}$} & $\begin{array}{l}\text { Experienced skilled } \\
\text { or skilled workers }\end{array}$ & 3,4 \\
\hline & $\begin{array}{l}\text { Basic or semi- } \\
\text { skilled workers }\end{array}$ & 1,2 \\
\hline
\end{tabular}

Table 3.3 gives the numbers of positions available at the various occupational categories at present. A pie-chart is shown in Figure 3.3.

Table 3.3- Distribution by occupational category

\begin{tabular}{|c|c|c|}
\hline \multicolumn{2}{|c|}{ Category } & $\begin{array}{c}\text { Number of } \\
\text { positions }\end{array}$ \\
\hline \multicolumn{2}{|c|}{ Decision making } & 642 \\
\hline \multicolumn{2}{|c|}{ Managers } & 1,911 \\
\hline \multicolumn{2}{|l|}{ Supervisors } & 4,096 \\
\hline \multirow{2}{*}{$\begin{array}{l}\text { Operational } \\
\text { Grades }\end{array}$} & $\begin{array}{l}\text { Experienced } \\
\text { skilled workers }\end{array}$ & 7,493 \\
\hline & $\begin{array}{l}\text { Basic or semi- } \\
\text { skilled workers }\end{array}$ & 13,393 \\
\hline
\end{tabular}

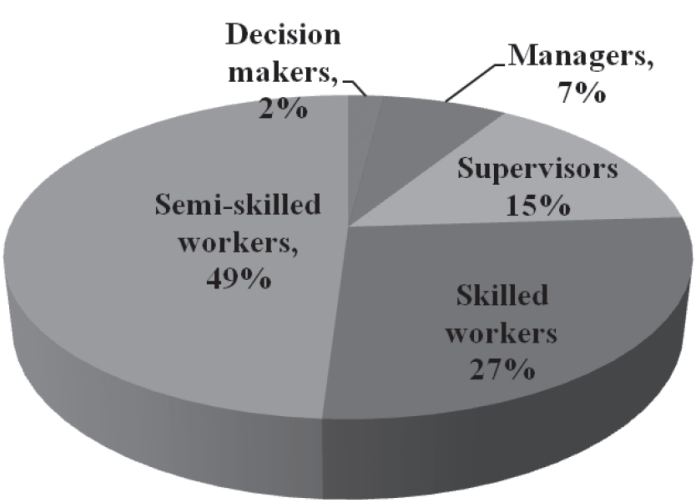

Figure 3.3- Distribution by occupational category

It is seen that the workers account for over three-quarters of the total workforce, while the decision makers and the managers account for less than one-tenth.

Figures 3.4 through 3.7 show the distribution of the highest qualifications. It is seen that the degree and management qualifications predominate at the higher categories, while the
O-Level and the A-Level qualifications predominate at the lowest categories of workers.

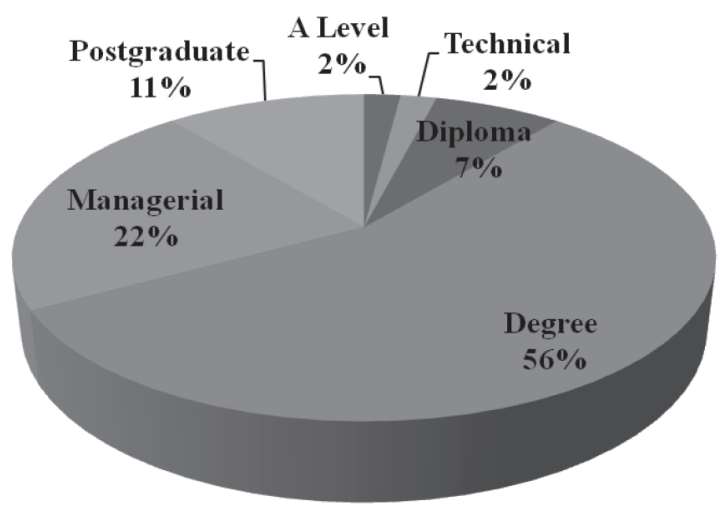

Figure 3.4- Decision Makers

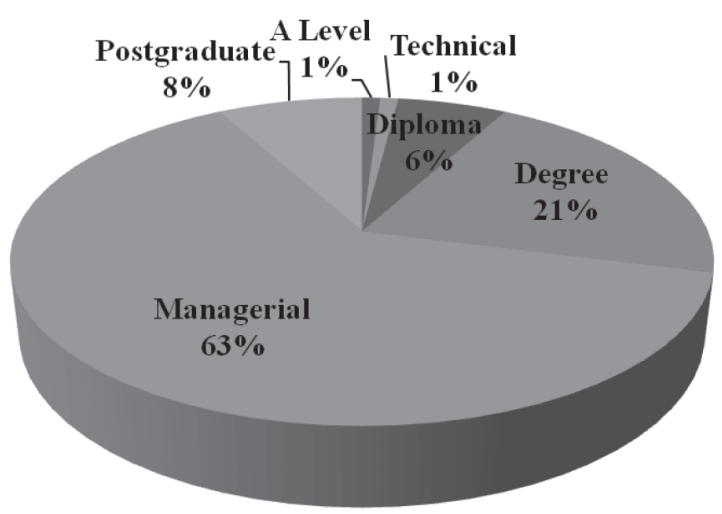

Figure 3.5- Managers

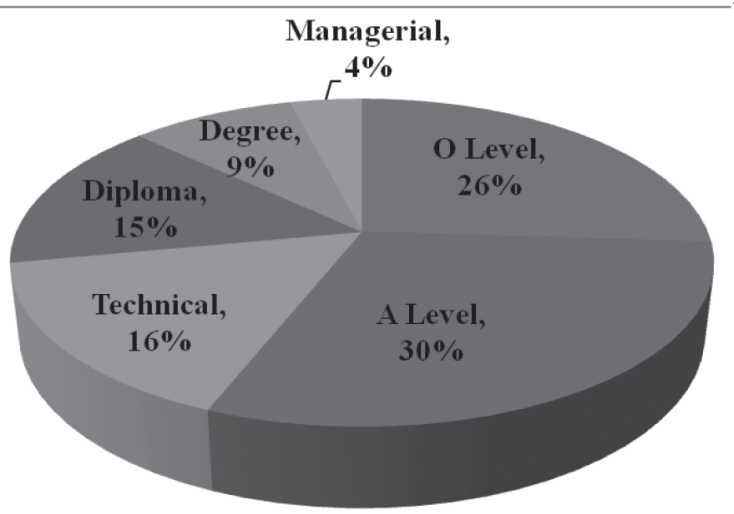

Figure 3.6- Supervisors

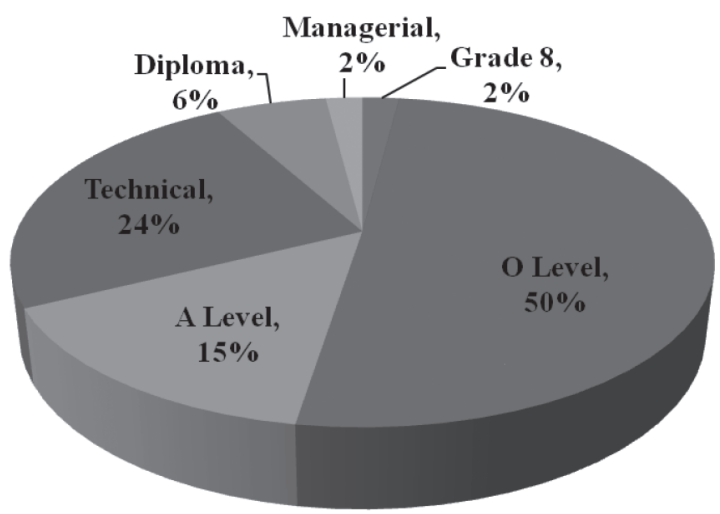

Figure 3.7- Operational grades 
Table 3.4- Educational qualifications at each occupational level

\begin{tabular}{|c|c|c|c|c|c|c|c|c|c|}
\hline $\begin{array}{l}\text { Employment } \\
\text { Category }\end{array}$ & Records & $\begin{array}{c}\text { Grade } \\
\quad 8\end{array}$ & $\mathrm{O} / \mathrm{L}$ & $\mathrm{A} / \mathrm{L}$ & $\begin{array}{l}\text { Tech } \\
\text { Course }\end{array}$ & Diploma & Degree & $\begin{array}{c}\text { Managerial } \\
\text { Qualification } \\
\text { (CIMA, } \\
\text { MBA) }\end{array}$ & $\begin{array}{c}\text { Post } \\
\text { graduate }\end{array}$ \\
\hline Decision making & 516 & 0 & 3 & 10 & 10 & 35 & 289 & 113 & 56 \\
\hline Managers & 1344 & 0 & 0 & 12 & 82 & 280 & 845 & 104 & 21 \\
\hline Supervisors & 3196 & 0 & 821 & 949 & 521 & 492 & 289 & 124 & 0 \\
\hline Operative grades & 746 & 12 & 372 & 114 & 182 & 45 & 1 & 20 & 0 \\
\hline
\end{tabular}

Table 3.4 gives the details of the actual qualifications held, and it is seen that multiple qualifications held by the workers.

Table 3.5- Gender distribution of workforce by establishment type

\begin{tabular}{|l|r|r|}
\hline $\begin{array}{c}\text { Establishment } \\
\text { type }\end{array}$ & Males & Females \\
\hline $\begin{array}{l}\text { Government } \\
\text { establishment }\end{array}$ & 1,272 & 160 \\
\hline $\begin{array}{l}\text { Private } \\
\text { establishment }\end{array}$ & 3,790 & 4,679 \\
\hline $\begin{array}{l}\text { Other } \\
\text { establishment }\end{array}$ & 6 & 3 \\
\hline
\end{tabular}

Table 3.5 shows that although the females in the government establishments is very low at just over $11 \%$, there is a higher employment of females in the private establishments, at around $55 \%$.

The employment disposition by age is shown in Figure 3.8. It is seen that the industry prefers to retain the experience of the age group $30-50$. High percentage of employees at the decision making category falls into the over 50 age group.

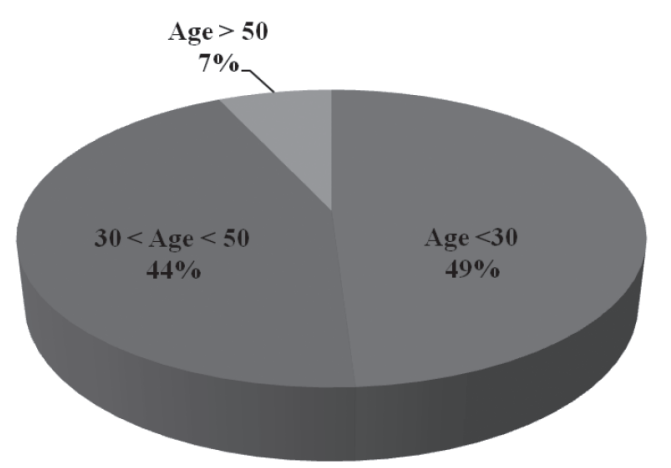

Figure 3.8-Composition of workforce by age

\subsection{Training Profile}

The profile of the training organisations was obtained mainly through the survey and from the web. The training requirements of the personnel in electrical and electronics industry depend on the employment category such as decision making, managers, supervisors and operational grades. The training capacities of organizations are summarised by considering the degree awarding universities, institutes offering diploma courses, and institutes for technical courses separately.

Technical and vocational education and training (TVET) has been implemented by a wide range of institutions in the public and private sectors. Most of the public sector institutions operate under the Ministry of Youth Affairs and Skills Development. In addition, many other ministries undertake training through departments and corporations as a secondary function. The available training capacities of the government training organisations for operational grades are summarised in Table A2.3. Similarly in the private sector some of the institutes provide training facilities and certificate courses suitable for operational grades. The training capacities of degree awarding institutions are given in Table A2.1. and the available capacities of diploma level courses are summarised in Table A2.2.

\section{Matching the Training with Industry Needs}

\subsection{The Forecast of Future Human Resource Needs}

The manpower requirement of the Electrical and Electronics industry sector has been estimated by considering not only the growth rate but also the employee movements and expansion plans of the industry obtained through the survey.

The estimated manpower opportunities in the electrical and electronic industry in the individual sub-sectors are given in Appendix A1 in tables A1.1 to A1.7 for the operational grades, supervisors and managers. 


\subsection{Training Provisions}

The deficits and excesses in the training provisions are identified by mapping the estimated manpower requirements and current training capacity. The employment opportunities in both formal and informal industry sectors are considered mainly in the operational grades. The mapping of the formal manpower requirement to the current training capacity in operational grades is given in Table A 3.1.

As the training courses are limited in number, the relevant occupations have been grouped and mapped against them. The Further it is found that the occupations and the training courses for the electrician and related occupations are intermingled in nature and thus the training capacities for these have been grouped together although the manpower requirements have been split into four categories. While these categories have a manpower requirement of 1654 in 2012 the current training capacity is 929 , which is $37.4 \%$ of the current training capacity. There is a deficit of 625 training provisions in electrician related areas. Similarly the other training programmes and related occupations are mapped. It is observed that there is a certain lack of capacity to deliver some skills/ competencies related to certain specialized fields such as skills/competencies related to automation and power plant operation. The training provisions in the diploma level and the degree level and the relevant manpower requirements are given in Appendix 1 and 2.

\section{Discussion and Conclusion}

A profile of the Electrical Engineering Industry including industry profile, human resource profile and training profile has been determined based on the data received from the survey.

The occupational structure has been broadly identified at occupational levels for the following sub-sectors in electrical and electronics industry: a) energy supply, b) electrical products/equipment, c) electrical services, d) export oriented electronics and e) Local consumer electronics and electronics services. From the surveyed companies, more than $76.8 \%$ are in the electrical industry and these companies account for over $81.1 \%$ of the total employment provided. The energy supply sub sector provided $36.7 \%$ of the total employment, and is influenced heavily by the large workforce of the CEB. The electrical services industry, which is mostly dominated by the small enterprises, contributes to $20.9 \%$, while electrical products sector accounts for $23.5 \%$ of the employment. Further the electronics sector provides employment only for $18.9 \%$ of the workforce.

The majority of the industry's employment is concentrated in the operational grades $(75.8 \%)$ where the technical skills requirements become quite specific for a particular role and quite diverse for different roles. The skills requirement become more generalized, with more emphasis for managerial qualifications, as one goes higher up in the occupational structure through supervisory (14.9\%), managerial (6.9\%) and decision making levels $(2.3 \%)$.

At the operational levels, the vast majority of the workers are with either GCE O/L or A/L qualifications $(65.2 \%)$. On the other hand, higher education qualifications are much more sought after at the managerial level and decision making level with $72.2 \%$ of the managers and $88.8 \%$ of the decision makers possessing a degree or above qualifications.

The growth potential of the electrical and electronic industry has been estimated, based on census and statistics of GDP growth rates of similar industries by categorising the industry into five sub-sectors. The forecasted annual growths of employment for the electrical and electronics industries are $13.7 \%$ and $16.8 \%$ respectively.

The training profile of the industry sector has been identified at operational grade level, diploma level and degree level. Further the estimated manpower requirements and the training provisions were mapped to identify the excess and deficits especially in the operational grades. The overall contribution of the informal sector employment $(62.6 \%)$ has been considered in the mapping exercise.

\section{Acknowledgement}

Authors wish to acknowledge the Tertiary and Vocational Education Commission (TVEC) of Sri Lanka in providing the funding and other assistance to undertake the study. They also wish to acknowledge the support given by Prof. Ranjit Perera and Dr. Asanka Rodrigo and wish to thank Eng. Buddhika Heendeniya and Eng. Sameera Roshan in doing much of the background work required. Data made available by Mr. Maldeni, Deputy Director of Export Development Board is also gratefully acknowledged. 


\section{References}

1. "National Policy Framework on Higher Education and Technical \& Vocation Education", Nation Education Commission, Sri Lanka, June 2009.

2. "Vocational Education and Training Plan for the Electrical and Electronic Engineering Industry", Tertiary and Vocational Education Commission, Sri Lanka, June 2012(Draft).

3. http://www.statistics.gov.lk/industry/ASI2009 .pdf Annual Survey of Industries 2009, Department of census and statistics.

4. http://www.statistics.gov.lk/samplesurvey/LF S_Annual\%20Report_2010.pdf Labour Force Survey - Annual Report 2010, Department of census and statistics.

5. http://www.statistics.gov.lk/national_accounts Summary indicators of GDP, Dept. of Census and Statistics, Visited 1 June 2012.

6. http://www.tvec.gov.lk Tertiary and Vocational Education Commission Website, Visited 1 June 2012.

7. http://www.techedu.gov.lk Statistical Handbook on Technical Education 2008/09, Department of Technical Education \& Training. 


\section{Appendix 1 - Estimated manpower requirements in individual subsectors}

The estimated manpower requirements of electrical and electronics sectors are given in Table A1.1 and

Table A1.2 respectively.

Table A1.1- Electrical sub sector

\begin{tabular}{|c|c|c|c|c|c|c|c|}
\hline \multirow{2}{*}{ Sub sector } & \multirow{2}{*}{ Category } & \multirow{2}{*}{$\begin{array}{c}\text { Total } \\
\text { workforce } \\
\text { in } 2011\end{array}$} & \multicolumn{5}{|c|}{ Predicted Manpower Opportunity } \\
\hline & & & 2012 & 2013 & 2014 & 2015 & 2016 \\
\hline \multirow{5}{*}{ 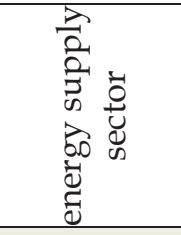 } & Decision making & 147 & 18 & 17 & 17 & 17 & 17 \\
\hline & Managers & 880 & 109 & 105 & 103 & 101 & 100 \\
\hline & Supervisors & 1,644 & 203 & 196 & 192 & 189 & 187 \\
\hline & Operative Grades & 8,548 & 1,055 & 1,020 & 997 & 982 & 974 \\
\hline & Total & 11,219 & 1,385 & 1,338 & 1,309 & 1,289 & 1,278 \\
\hline \multirow{5}{*}{ 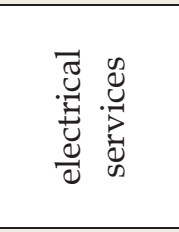 } & Decision making & 598 & 68 & 66 & 64 & 63 & 63 \\
\hline & Managers & 1,056 & 121 & 117 & 115 & 113 & 112 \\
\hline & Supervisors & 3,276 & 373 & 361 & 352 & 347 & 344 \\
\hline & Operative Grades & 6,590 & 825 & 798 & 780 & 768 & 762 \\
\hline & Total & 11,520 & 1,387 & 1,342 & 1,311 & 1,291 & 1,281 \\
\hline \multirow{5}{*}{ 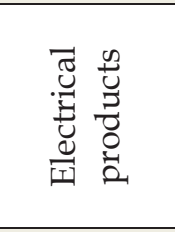 } & Decision making & 268 & 45 & 45 & 45 & 46 & 46 \\
\hline & Managers & 784 & 135 & 135 & 135 & 136 & 136 \\
\hline & Supervisors & 964 & 164 & 164 & 165 & 165 & 166 \\
\hline & Operative Grades & 10,944 & 1,879 & 1,884 & 1,888 & 1,893 & 1,898 \\
\hline & Total & 12,960 & 2,223 & 2,228 & 2,233 & 2,240 & 2,246 \\
\hline \multirow{5}{*}{ 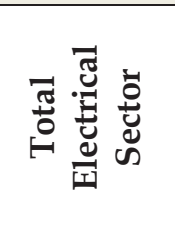 } & Decision making & 1013 & 131 & 128 & 126 & 126 & 126 \\
\hline & Managers & 2720 & 365 & 357 & 353 & 350 & 348 \\
\hline & Supervisors & 5884 & 740 & 721 & 709 & 701 & 697 \\
\hline & Operative Grades & 26,082 & 3,759 & 3,702 & 3,665 & 3,643 & 3,634 \\
\hline & Total & 35,699 & 4,995 & 4,908 & 4,853 & 4,820 & 4,805 \\
\hline
\end{tabular}

Table A1.2- Electronics sub sector

\begin{tabular}{|c|c|c|c|c|c|c|c|}
\hline \multirow[b]{2}{*}{ Sub sector } & \multirow[b]{2}{*}{ Category } & \multirow{2}{*}{$\begin{array}{c}\text { Total } \\
\text { workforce } \\
\text { in } 2011\end{array}$} & \multicolumn{5}{|c|}{ Manpower requirement } \\
\hline & & & 2012 & 2013 & 2014 & 2015 & 2016 \\
\hline \multirow{5}{*}{ 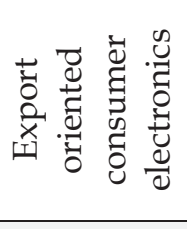 } & Decision making & 52 & 9 & 9 & 9 & 9 & 9 \\
\hline & Managers & 152 & 25 & 25 & 25 & 25 & 25 \\
\hline & Supervisors & 398 & 66 & 66 & 66 & 66 & 66 \\
\hline & Operative Grades & 7,584 & 1,259 & 1,262 & 1,266 & 1,269 & 1,272 \\
\hline & Total & 8,186 & 1,359 & 1,362 & 1,366 & 1,369 & 1,372 \\
\hline \multirow{5}{*}{ 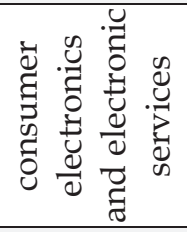 } & Decision making & 140 & 24 & 24 & 24 & 24 & 24 \\
\hline & Managers & 286 & 50 & 50 & 50 & 50 & 50 \\
\hline & Supervisors & 554 & 94 & 94 & 94 & 95 & 95 \\
\hline & Operative Grades & 1218 & 209 & 209 & 210 & 210 & 211 \\
\hline & Total & 2198 & 377 & 377 & 378 & 379 & 380 \\
\hline \multirow{5}{*}{ 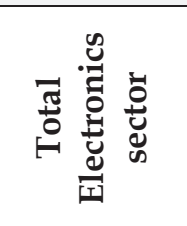 } & Decision making & 192 & 33 & 33 & 33 & 33 & 33 \\
\hline & Managers & 438 & 75 & 75 & 75 & 75 & 75 \\
\hline & Supervisors & 952 & 160 & 160 & 160 & 161 & 161 \\
\hline & Operative Grades & 8,802 & 1,468 & 1,471 & 1,476 & 1,479 & 1,483 \\
\hline & Total & 10,384 & 1,736 & 1,739 & 1,744 & 1,748 & 1,752 \\
\hline
\end{tabular}


The estimated manpower requirement of the major operational grades of the electrical and the electronics sectors are given in Table A1.3 and A1.4 respectively.

Table A1.3- Operational grades in Electrical sector

\begin{tabular}{|l|c|r|r|r|r|r|}
\hline & \multicolumn{7}{|c|}{$\begin{array}{c}\text { Current } \\
\text { Workforce in } \mathbf{2 0 1 1}\end{array}$} & \multicolumn{4}{|c|}{ Estimated manpower requirement } \\
\cline { 5 - 7 } Occupation & $\mathbf{2 0 1 2}$ & $\mathbf{2 0 1 3}$ & $\mathbf{2 0 1 4}$ & $\mathbf{2 0 1 5}$ & $\mathbf{2 0 1 6}$ \\
\hline Machine Operator & 610 & 600 & 594 & 591 & 589 \\
\hline Electrician & 2,824 & 406 & 400 & 396 & 393 & 392 \\
\hline Technician & 2,322 & 335 & 330 & 326 & 324 & 324 \\
\hline Unskilled Worker & 1,949 & 214 & 207 & 202 & 199 & 197 \\
\hline Worker & 1,768 & 255 & 251 & 248 & 247 & 246 \\
\hline Semi-Skilled Technical Worker & 1,522 & 167 & 161 & 158 & 155 & 154 \\
\hline Lineman & 1,299 & 142 & 138 & 135 & 133 & 131 \\
\hline Trainee & 1,022 & 147 & 145 & 144 & 143 & 142 \\
\hline Helper & 908 & 131 & 129 & 128 & 127 & 127 \\
\hline Trainee Technician & 824 & 93 & 90 & 88 & 87 & 87 \\
\hline Production Worker & 788 & 114 & 112 & 111 & 110 & 110 \\
\hline Technician/Electrician & 696 & 100 & 99 & 98 & 97 & 97 \\
\hline Electrical Assistant & 478 & 69 & 68 & 67 & 67 & 67 \\
\hline Control Room Operator & 419 & 46 & 44 & 43 & 43 & 42 \\
\hline Labourer & 408 & 59 & 58 & 57 & 57 & 57 \\
\hline Production Assistant & 400 & 58 & 57 & 56 & 56 & 56 \\
\hline Skilled Technical Worker & 343 & 38 & 36 & 36 & 35 & 35 \\
\hline
\end{tabular}

Table A1.4- Operational grades in Electronics sector

\begin{tabular}{|l|r|r|r|r|r|r|}
\hline & \multirow{2}{*}{$\begin{array}{c}\text { Current workforce } \\
\text { in 2011 }\end{array}$} & \multicolumn{5}{|l|}{ Estimated manpower requirement } \\
\cline { 3 - 7 } Occupation & 3,944 & $\mathbf{2 0 1 2}$ & $\mathbf{2 0 1 3}$ & $\mathbf{2 0 1 4}$ & $\mathbf{2 0 1 5}$ & $\mathbf{2 0 1 6}$ \\
\hline Production Worker & 2,336 & 390 & 659 & 661 & 663 & 665 \\
\hline Production Line Worker & 948 & 158 & 158 & 392 & 393 & 394 \\
\hline Operator & 376 & 63 & 63 & 63 & 159 & 160 \\
\hline Technician & 116 & 19 & 19 & 19 & 19 & 63 \\
\hline Electrician & 106 & 18 & 18 & 18 & 18 & 20 \\
\hline Technician/Electrician & 80 & 13 & 13 & 13 & 13 & 13 \\
\hline Helper & 60 & 10 & 10 & 10 & 10 & 10 \\
\hline Cleaner & 48 & 8 & 8 & 8 & 8 & 8 \\
\hline Production Process Worker & & & & &
\end{tabular}

The estimated manpower requirement of the major supervisory grades are given in Table A1.5 and A1.6 respectively.

Table A1.5- Supervisory grades in Electrical sector

\begin{tabular}{|l|c|r|r|r|r|r|}
\hline & \multirow{2}{*}{$\begin{array}{c}\text { Current workforce } \\
\text { in 2011 }\end{array}$} & \multicolumn{4}{|c|}{ Estimated manpower requirement } \\
\cline { 3 - 7 } Occupation & $\mathbf{2 0 1 2}$ & $\mathbf{2 0 1 3}$ & $\mathbf{2 0 1 4}$ & $\mathbf{2 0 1 5}$ & $\mathbf{2 0 1 6}$ \\
\hline Electrical Supervisor & 1,382 & 174 & 169 & 167 & 165 & 164 \\
\hline Electrical Superintendent & 1,192 & 131 & 127 & 125 & 123 & 122 \\
\hline Workshop Supervisor & 1,034 & 130 & 127 & 125 & 123 & 122 \\
\hline Supervisor & 520 & 65 & 64 & 63 & 62 & 62 \\
\hline Engineering Assistant & 279 & 34 & 32 & 32 & 32 & 32 \\
\hline Team Leader & 164 & 21 & 20 & 20 & 20 & 19 \\
\hline Engineer & 134 & 17 & 16 & 16 & 16 & 16 \\
\hline Superintendent & 130 & 15 & 15 & 15 & 15 & 14 \\
\hline Assistant Engineer & 100 & 13 & 12 & 12 & 12 & 12 \\
\hline Mechanical Superintendent & 91 & 10 & 10 & 10 & 10 & 10 \\
\hline Foreman & 76 & 10 & 9 & 9 & 9 & 9 \\
\hline
\end{tabular}


Table A1.6- Supervisory grades in Electronics sector

\begin{tabular}{|l|r|r|r|r|r|r|}
\hline & \multirow{2}{*}{$\begin{array}{c}\text { Current workforce } \\
\text { in 2011 }\end{array}$} & \multicolumn{4}{|c|}{ Estimated manpower requirement } \\
\cline { 3 - 7 } Occupation & 2012 & 2013 & 2014 & 2015 & 2016 \\
\hline Supervisor & 214 & 36 & 36 & 36 & 36 & 36 \\
\hline Engineer & 196 & 33 & 33 & 33 & 33 & 33 \\
\hline Team Leader & 106 & 18 & 18 & 18 & 18 & 18 \\
\hline Group Leader & 86 & 14 & 14 & 14 & 15 & 15 \\
\hline Technical Officer & 76 & 13 & 13 & 13 & 13 & 13 \\
\hline Electrical Supervisor & 58 & 10 & 10 & 10 & 10 & 10 \\
\hline
\end{tabular}

The estimated manpower requirements of major managerial grades of electrical and electronics sectors are given in Table A1.7 and A1.8 respectively.

Table A1.7- Managers in Electrical sector

\begin{tabular}{|l|c|c|c|c|c|c|}
\hline & \multirow{2}{*}{$\begin{array}{c}\text { Current } \\
\text { workforce in }\end{array}$} & \multicolumn{3}{|l|}{ Estimated manpower requirement } \\
\cline { 3 - 8 } Occupation & 2011 & 2012 & 2013 & 2014 & 2015 & 2016 \\
\hline Electrical Engineer & 876 & 103 & 100 & 99 & 98 & 97 \\
\hline Engineer & 330 & 44 & 43 & 43 & 42 & 42 \\
\hline Manager & 180 & 24 & 24 & 23 & 23 & 23 \\
\hline Engineer Mechanical/Civil/Other & 155 & 18 & 18 & 18 & 18 & 17 \\
\hline Sales/Commercial/Customer & 108 & 14 & 14 & 14 & 14 & 14 \\
Manager & 88 & 12 & 12 & 11 & 11 & 11 \\
\hline HR and Administrative Manager & 84 & 11 & 11 & 11 & 11 & 11 \\
\hline Executive & 80 & 11 & 11 & 10 & 10 & 10 \\
\hline Assistant Engineer & 68 & 9 & 9 & 9 & 9 & 9 \\
\hline Plant Manager & 66 & 9 & 9 & 9 & 8 & 8 \\
\hline Project Manager & 64 & 9 & 8 & 8 & 8 & 8 \\
\hline Assistant Manager & 56 & 8 & 7 & 7 & 7 & 7 \\
\hline R\&D and Technical Manager & & & & & & \\
\hline
\end{tabular}

Table A1.8- Managers in Electronics sector

\begin{tabular}{|l|c|r|r|r|r|r|}
\hline & \multirow{2}{*}{$\begin{array}{c}\text { Current } \\
\text { workforce } \\
\text { Occupation }\end{array}$} & \multicolumn{6}{|c|}{ Estimated manpower requirement } \\
\cline { 5 - 8 } & in 2011 & 2012 & 2013 & 2014 & 2015 & 2016 \\
\hline Engineer & 114 & 20 & 20 & 20 & 20 & 20 \\
\hline Manager & 88 & 15 & 15 & 15 & 15 & 15 \\
\hline Design Engineer & 42 & 7 & 7 & 7 & 7 & 7 \\
\hline Executive & 26 & 4 & 4 & 4 & 4 & 4 \\
\hline Assistant Manager & 20 & 3 & 3 & 3 & 3 & 3 \\
\hline Quality Assurance Manager & 18 & 3 & 3 & 3 & 3 & 3 \\
\hline $\begin{array}{l}\text { HR and Administrative } \\
\text { Manager }\end{array}$ & 12 & 2 & 2 & 2 & 2 & 2 \\
\hline Operational Manager & 12 & 2 & 2 & 2 & 2 & 2 \\
\hline
\end{tabular}


Appendix 2 - Training Capacities in the Electrical and Electronics Industry

Table A2.1- Training capacity in universities

\begin{tabular}{|c|c|c|c|c|c|}
\hline Institution & Course & Specialisation & $\begin{array}{c}\text { Duration } \\
\text { (years) }\end{array}$ & Nature & $\begin{array}{l}\text { Annual } \\
\text { Capacity }\end{array}$ \\
\hline \multirow{2}{*}{$\begin{array}{l}\text { University of } \\
\text { Moratuwa }\end{array}$} & $\begin{array}{l}\text { Bachelor of Science of } \\
\text { Engineering }\end{array}$ & Electrical Engineering & 4 & Fulltime & 100 \\
\hline & $\begin{array}{l}\text { Bachelor of Science of } \\
\text { Engineering }\end{array}$ & $\begin{array}{l}\text { Electronics and } \\
\text { telecommunication Eng }\end{array}$ & 4 & Fulltime & 100 \\
\hline $\begin{array}{l}\text { University of } \\
\text { Peradeniya }\end{array}$ & $\begin{array}{l}\text { Bachelor of Science of } \\
\text { Engineering }\end{array}$ & $\begin{array}{l}\text { Electrical and Electronics } \\
\text { Engineering }\end{array}$ & 4 & Fulltime & 100 \\
\hline $\begin{array}{l}\text { University of } \\
\text { Ruhuna }\end{array}$ & $\begin{array}{l}\text { Bachelor of Science of } \\
\text { Engineering }\end{array}$ & $\begin{array}{l}\text { Electrical and } \\
\text { Information Engineering }\end{array}$ & 4 & Fulltime & 75 \\
\hline \multirow{2}{*}{$\begin{array}{l}\text { Open University } \\
\text { of Sri Lanka }\end{array}$} & $\begin{array}{l}\text { Bachelor of } \\
\text { Technology in } \\
\text { Engineering } \\
\end{array}$ & $\begin{array}{l}\text { Electronic and } \\
\text { Communication } \\
\text { Engineering }\end{array}$ & 4 & Distance & \\
\hline & $\begin{array}{l}\text { Bachelor of } \\
\text { Technology in } \\
\text { Engineering }\end{array}$ & Electrical Engineering & 4 & Distance & \\
\hline \multirow{2}{*}{$\begin{array}{l}\text { Kotalawala } \\
\text { Defence } \\
\text { Univeristy }\end{array}$} & $\begin{array}{l}\text { Bachelor of Science of } \\
\text { Engineering }\end{array}$ & $\begin{array}{l}\text { Electrical and electronic } \\
\text { Engineering }\end{array}$ & 4 & Fulltime & 30 \\
\hline & $\begin{array}{l}\text { Bachelor of Science of } \\
\text { Engineering }\end{array}$ & $\begin{array}{l}\text { Electronics } \\
\text { and telecommunication } \\
\text { engineering }\end{array}$ & 4 & Fulltime & 30 \\
\hline \multirow{2}{*}{ UNIVOTEC } & $\begin{array}{l}\text { Bachelor of } \\
\text { Technology }\end{array}$ & Mechatronics Technology & $\begin{array}{c}3 \text { (basic) } \\
4 \text { (special) }\end{array}$ & $\begin{array}{l}\text { Part } \\
\text { time }\end{array}$ & 25 \\
\hline & $\begin{array}{l}\text { Bachelor of } \\
\text { Technology }\end{array}$ & $\begin{array}{l}\text { Building Services } \\
\text { Technology }\end{array}$ & $\begin{array}{c}3 \text { (basic) } \\
4 \text { (special) }\end{array}$ & $\begin{array}{l}\text { Part } \\
\text { time }\end{array}$ & 25 \\
\hline \multicolumn{5}{|c|}{ Total } & 485 \\
\hline
\end{tabular}

Note: Graduates from private universities and foreign universities are not included

Table A2.2- Training capacity of Diploma courses in electrical and electronics field

\begin{tabular}{|c|c|c|c|c|c|}
\hline Institution & Course & Area & $\begin{array}{c}\text { Duration } \\
\text { (years) }\end{array}$ & Nature & $\begin{array}{l}\text { Annual } \\
\text { Capacity }\end{array}$ \\
\hline \multirow{2}{*}{ ITUM } & \multirow{2}{*}{$\begin{array}{l}\text { National Diploma in } \\
\text { Technology (NDT) }\end{array}$} & Electrical & 3 years & Full time & 40 \\
\hline & & $\begin{array}{l}\text { Electronic and } \\
\text { Telecommunication }\end{array}$ & 3years & Full time & 40 \\
\hline SLIATE & $\begin{array}{l}\text { Higher National } \\
\text { Diploma in Engineering } \\
\text { (HNDE) }\end{array}$ & Electrical/ Electronics & & Full time & \\
\hline \multirow[t]{2}{*}{ NAITA-IET } & \multirow{2}{*}{$\begin{array}{l}\text { National Diploma in } \\
\text { Engineering Sciences } \\
\text { (NDES) }\end{array}$} & Electronics & & Full time & 30 \\
\hline & & Electrical Power & & Full time & 50 \\
\hline \multicolumn{5}{|c|}{ Total } & 160 \\
\hline
\end{tabular}


Table A2.3- Training capacity in government training institutions

\begin{tabular}{|c|c|c|c|c|c|c|}
\hline $\begin{array}{l}\text { Occupation } \\
\text { Area }\end{array}$ & & Institution & Course Name & 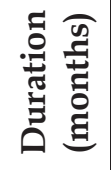 & 丞赵 & 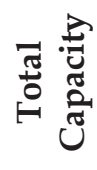 \\
\hline \multirow{2}{*}{$\begin{array}{l}\text { Electrical } \\
\text { Appliances } \\
\text { Repairer }\end{array}$} & E & DTET & $\begin{array}{l}\text { Certificate in Household Electrical } \\
\text { Appliances Repairing }\end{array}$ & 6 & 125 & \multirow{2}{*}{233} \\
\hline & $\mathrm{E}$ & VTA & $\begin{array}{l}\text { Household Electrical \& Electronic } \\
\text { Equipment Repairer }\end{array}$ & 6 & 108 & \\
\hline $\begin{array}{l}\text { Electrical } \\
\text { Installation } \\
\text { worker }\end{array}$ & E & DTET & Electrical Installation work(MC) & 6 & 17 & 17 \\
\hline \multirow{3}{*}{$\begin{array}{l}\text { Electrical } \\
\text { Wiring } \\
\text { related } \\
\text { worker }\end{array}$} & $\mathrm{E}$ & DTET & Certificate in Electrical Trade & 6 & 99 & \multirow{3}{*}{171} \\
\hline & E & DTET & Electrical wiring & 6 & 9 & \\
\hline & $\mathrm{E}$ & DTET & Electrical wiring(MC) & 6 & 63 & \\
\hline \multirow{7}{*}{ Electrician } & E & DTET & Electrician-NVQ LEVEL 03 & 12 & 28 & \multirow{7}{*}{1902} \\
\hline & E & DTET & NCECP Industrial Electrician & 24 & 750 & \\
\hline & E & DTET & Electrician(MC) & 6 & 15 & \\
\hline & E & CGTTI & Electrical power & 42 & 40 & \\
\hline & E & $\begin{array}{l}\text { Youth } \\
\text { Center- } \\
\text { NYSC } \\
\end{array}$ & Electrician & 12 & 15 & \\
\hline & E & $\begin{array}{l}\text { NAITA- } \\
\text { ATI }\end{array}$ & Electrician (special) & 36 & 36 & \\
\hline & $\mathrm{E}$ & VTA & Electrician & 6 & 1018 & \\
\hline \multirow{3}{*}{$\begin{array}{l}\text { Electronic } \\
\text { equipment } \\
\text { repairer }\end{array}$} & EN & DTET & $\begin{array}{l}\text { Certificate in Radio, TV, \& Allied Equipment } \\
\text { Repairing }\end{array}$ & 6 & 14 & \multirow{3}{*}{161} \\
\hline & EN & VTA & Radio, TV And Allied Equipment Repairer & 6 & 132 & \\
\hline & EN & $\begin{array}{l}\text { Youth } \\
\text { Center- } \\
\text { NYSC }\end{array}$ & Radio and TV Allied Equipment Repairer & 12 & 15 & \\
\hline $\begin{array}{l}\text { Motor } \\
\text { Winder }\end{array}$ & E & VTA & Electric Motor Winder & 6 & 104 & 104 \\
\hline $\begin{array}{l}\text { Technical } \\
\text { Officer }\end{array}$ & $\begin{array}{l}\text { E/ } \\
\text { EN }\end{array}$ & DTET & $\begin{array}{l}\text { National Certificate for Industrial } \\
\text { Technicians (Electrical \& Electronics } \\
\text { Engineering) }\end{array}$ & 24 & 117 & 117 \\
\hline \multirow[b]{2}{*}{ Technician } & $\mathrm{EN}$ & DTET & NCECP Electronics & 24 & 645 & \multirow[b]{2}{*}{701} \\
\hline & $\mathrm{EN}$ & $\begin{array}{l}\text { NAITA- } \\
\text { ATI }\end{array}$ & Electronics Craftsman (Special) & 36 & 56 & \\
\hline \multirow[t]{2}{*}{$\begin{array}{l}\text { Computer } \\
\text { hardware } \\
\text { technician }\end{array}$} & EN & $\begin{array}{l}\text { Youth } \\
\text { Center- } \\
\text { NYSC }\end{array}$ & Computer hardware technician & 6 & 30 & \multirow[t]{2}{*}{166} \\
\hline & EN & VTA & Computer Hardware Technician & 6 & 136 & \\
\hline
\end{tabular}

Note: E-Electrical, EN-Electronics, MC- Mahinda Chinthana

NCECP-National Certificate in Engineering Craft Practice

Sources: Statistical Handbook on Technical Education 2008/09, Department of Technical Education \& Training, http://www.techedu.gov.lk [7]

Prospectus 2009 / 2010, , Department of Technical Education \& Training, http://www.techedu.gov.lk

Survey on Electrical and Electronics Industry sector 
Appendix A3 - Deficits and Excess in Training Provisions

Table A3.1: Mapping of manpower requirement to training capacity in operational grades

\begin{tabular}{|c|c|c|c|}
\hline Relevant occupation & $\begin{array}{l}\text { Manpower } \\
\text { requirement } \\
\text { in } 2012 \\
\end{array}$ & Area of Training Course & $\begin{array}{l}\text { Current } \\
\text { Training } \\
\text { Capacity }\end{array}$ \\
\hline $\begin{array}{l}\text { Technician, Electrician, Electrical } \\
\text { Assistant, Fitter, Electrical Helper, } \\
\text { Electrical Trainee, }\end{array}$ & 651 & Electrician & \multirow{5}{*}{929} \\
\hline $\begin{array}{l}\text { Repairman, Fan Technician, } \\
\text { Serviceman, AC Technician, } \\
\text { Sewing Machine Technician }\end{array}$ & 9 & $\begin{array}{l}\text { Electrical appliance repairer/ } \\
\text { Electronics equipment repairer }\end{array}$ & \\
\hline Wireman, Lineman, Jointer & 152 & $\begin{array}{c}\text { Electrical wiring related } \\
\text { worker }\end{array}$ & \\
\hline $\begin{array}{l}\text { Technician, Semi-Skilled Technical } \\
\text { Worker, Trainee Technician, Skilled } \\
\text { Technical Worker, Technical } \\
\text { Assistant, Junior Technician, Test } \\
\text { Bench Technician, Junior Foreman, } \\
\text { Assembly Line Technician, } \\
\text { Workshop Technician, Trainee, } \\
\text { Trainee Worker }\end{array}$ & 842 & Electrician, EW, EAR, EER & \\
\hline $\begin{array}{ll}\text { Sub-Total } \\
\end{array}$ & 1654 & & \\
\hline Motor Winder, Winder & 3 & Motor Winder & 39 \\
\hline $\begin{array}{l}\text { Operator, Electronic Technician, } \\
\text { Technician-EN, Technical } \\
\text { Assistant-EN, Trainee Technician- } \\
\text { EN, Craftsman, Hearing Aid Fitter, } \\
\text { Programmer, Barcode } \\
\text { Painter/Printer/Worker, } \\
\text { Computer Repairman } \\
\end{array}$ & 246 & Technician (Electronics) & 262 \\
\hline $\begin{array}{l}\text { Production Worker, Production } \\
\text { Line Worker, Packaging Line } \\
\text { Worker, Production Assistant, } \\
\text { Factory Worker, Section } \\
\text { Supervisor, Team Leader, Process } \\
\text { Leader, Production Process } \\
\text { Worker, Project Officer, Site } \\
\text { Officer, Data Entry Operator }\end{array}$ & 1257 & In house training & - \\
\hline $\begin{array}{l}\text { Unskilled Worker, Worker, Helper, } \\
\text { Labourer, Helper Loading, Helper } \\
\text { Packing, Helper Production, } \\
\text { Mechanical Helper, Helper Boiler, } \\
\text { Helper Quality, Machine Helper, } \\
\text { Office Assistant, Field Assistant, } \\
\text { Workshop Helper, Maintenance } \\
\text { Helper, Cleaner, Laboratory } \\
\text { Assistant, Data Processor }\end{array}$ & 834 & & - \\
\hline Automation Technician & 9 & AT-NEW & - \\
\hline $\begin{array}{l}\text { Power Plant Operator, Power } \\
\text { House assistant, Power Plant } \\
\text { Assistant, Control Room Operator }\end{array}$ & 78 & PP-NEW & - \\
\hline Total & 4081 & & 1230 \\
\hline
\end{tabular}

Note: The current training capacity is calculated by assuming that the only $37.4 \%$ of trained personnel remain in the formal industry sector. 
